\title{
Motivating Russian Workers: Analysis of Age and Gender Differences
}

\author{
By: Susan J. Linz
}

William Davidson Working Paper Number 466

February 2002 
Motivating Russian Workers: Analysis of Age and Gender Differences

\author{
Susan J. Linz \\ Department of Economics \\ Michigan State University \\ 101 Marshall Hall \\ East Lansing, Michigan 48824 \\ (517) 353-7280 \\ linz@msu.edu \\ Research Fellow \\ William Davidson Institute \\ University of Michigan
}

February 2002

Research for this paper was supported by a grant from the International Research \& Exchanges Board, with funds provided by the U.S. Department of State (Title VIII Program) and the National Endowment for the Humanities. None of these organizations is responsible for the views expressed. I thank Patricia Huddleston and Linda Good for allowing me to modify and use their survey instrument. 


\title{
William Davidson Institute Working Paper 466
}

\section{Motivating Russian Workers: Analysis of Age and Gender Differences}

\begin{abstract}
What motivates Russians to work? This paper utilizes survey data collected in May/June 2000 from 1200 employees in three regions of Russia to analyze the gender and generational differences in factors influencing motivation to work. Five main results emerge. First, Russians are not significantly different from their counterparts in the United States in terms of what is important to them at their place of work. Organizational commitment, however, emerges as only weakly positive among Russian workers; among managers the signal is much stronger. Second, there is little confusion on the part of managers regarding what is important to their workers. Managers' only mistake was to think workers valued their praise. Third, Russian workers have very low expectations of receiving any reward which they desire. This result, similar to results generated by American workers in the mid-1980s, is especially strong among the women and the older generation of workers participating in this survey. Fourth, gender differences involve the relative importance of particular motivators rather than differences in the ranking of motivators from most important to least important. That is, the Russian women participating in this project tended to express stronger feelings toward each of the motivators than the men, but the women did not rank order the motivators any differently than the men. Fifth, in many instances, generational differences disappeared when work experience was held constant. Age was only significant when expectation of receiving a particular reward was involved.
\end{abstract}

Keywords: Russia, motivation, gender, transition JEL Classification: J28, P23 


\section{William Davidson Institute Working Paper 466}

\section{Motivating Russian Workers: Analysis of Age and Gender Differences}

Russia's transition toward a market economy, initiated in January 1992, generated a large literature which analyzes the production and employment changes required and/or adopted by former state-owned enterprises. While a broad consensus has been reached regarding what must be done to enable privatized firms to succeed in the post-transition environment, ${ }^{1}$ debate continues regarding the nature and scope of what has been done by Russian firms. ${ }^{2}$ Few studies, however, focus on the extent to which managers need to adopt reward structures designed to improve job performance (Huddleston and Good 1999, Linz 2001, Linz and Krueger 1996, Puffer 1997, Upchurch et al 2000). ${ }^{3}$ In part, this stems from the rather unusual situation in Russia where firms delay wage payments for several months and employees still show up for work (Clarke 1999, Friebel and Guriev 2000, Kolev 1998). Thus, employee motivation has been considered less important to analyses of firm performance than access to financing for restructuring or the role of barter transactions, for example. The relatively few studies of employee motivation and reward structures in Russia also stem, in part, from data constraints (Buchko et al 1998, Gimpelson and Lippoldt 2001, Manning et al 2000). Consequently, we know little about what motivates Russians to work, and whether this varies by age or gender.

Several factors underscore the importance of understanding what motivates Russians to work. First, understanding what motivates Russians to work will enable managers, both domestic and foreign, to better evaluate reward structures designed to improve labor productivity. Numerous studies suggest that in the

\footnotetext{
${ }^{1}$ See, for example, Aghion and Carlin (1996), Anderson et al (1999), Brada (1996), Claessens and Djankov (1999), Djankov and Murrell (2000), Earle and Telegdy (1998),Ericson (1996), and Estrin et al (1995).

${ }^{2}$ See, for example, Barberis et al (1996), Blasi et al (1997), Broadman (2000), Ernst et al (1996), Filatotchev et al (1999), Gaddy and Ickes (1998), Izyumov et al (2000), Jones (1998), Linz (1997 2001), Linz and Krueger (1998), Polonsky and Aivazian (2000), and Treisman (2000).

${ }^{3}$ Several studies explore the importance of managers and incentive structures in motivating work in the former Soviet economy. See, for example, Ivancevich et al (1992), Lawrence and Vlachoutsicos (1990), Luthans et al (1993), May and Bormann (1993), McCarthy and Puffer (1992), Shaw et al (1991), Silverthorne (1992), Standing (1991), Welsh et al (1993a, 1993b).
} 


\section{William Davidson Institute Working Paper 466}

Soviet economy managers had difficulty creating an environment conducive to employee motivation (Berliner 1957, Granick 1987, Ivancevich et al 1992, Linz 1995 1998, Hauslohner 1987). Consequently, in Russia’s transition environment, especially after privatization, managers of former state-owned enterprises are likely to have found little in their experience to draw upon in terms of motivating workers. Moreover, anecdotal evidence highlighting the difficulties encountered in Russia by managers of joint ventures and foreign-owned subsidiaries in their daily operations, as well as their employee-training programs, pepper the international business literature. ${ }^{4}$ Finally, in Russia's liquidity-constrained environment, finding ways to increase (or improve the quality of) output without incurring additional cost is uppermost in the minds of many Russian managers (Krueger 2002, Krueger and Linz 2001, Linz and Krueger 1996). Understanding what motivates Russians to work will facilitate adoption of effective reward structures.

Second, understanding what motivates Russians to work will not only permit assessment of the extent to which conventional motivation theory, developed on the basis of research conducted in the United States, has relevance for Russia, but also will help to gauge the extent to which intercultural management techniques are required (Adler 1983 1990, Dowling and Schuler 1990). There is little reason to presume $a$ priori that American emphasis on individualism, rationality and equity as a framework for developing theories of motivation apply to the Russian case. Bartolome and Evans (1979), Fisher and Yuan (1998), Hofstede (1980) and Silverthorne (1992) offer compelling evidence of country and cultural differences in motivational factors.

Third, replicating previous studies facilitates a check on the robustness of their findings. Existing studies of worker motivation completed in Russia to date, while somewhat limited in scope,${ }^{5}$ present results

\footnotetext{
${ }^{4}$ The Financial Times, Wall Street Journal and The Economist offered a wealth of articles describing efforts of foreign businessmen in Russia during the early stages of the transition process; if not daily, then weekly, publishing stories which rivaled current fiction. Rose Brady, Moscow correspondent for Business Week from 1993 to 1996 , regularly provided detailed descriptions, many of which have been summarized in her recent book (1999). For detailed discussion of problems, see Shama (1993), and Sherr et al (1991), for example.

${ }^{5}$ Buchko et al (1998) conducted a survey in 1994 of 180 employees from a single manufacturing firm in Saratov. Huddleston and Good (1999) surveyed 675 retail workers in Russia (Moscow and St. Petersburg/Pushkin) and Poland
} 


\section{William Davidson Institute Working Paper 466}

that are not at odds with conventional wisdom regarding worker motivation. Combined, the studies address three main themes in the current motivation literature: the role of organizational commitment, the relative importance of various job motivators, and the expectation of receiving desired rewards in exchange for performance. One component of this project replicates the Huddleston and Good (1999) questionnaire, with minor modifications. Extending their analysis to include all three themes and a broader range of participants moves us closer to understanding what motivates Russians to work.

Fourth, investigating the existence of gender or generational differences in factors influencing the motivation to work establishes a foundation for designing an effective reward structure. Given Russia's economic and cultural history (Gregory and Kohlhase 1988, Ledeneva 1999, Millar 1987, Newell and Reilly 1996, Ofer and Vinokur 1992), we expect to find women's attitudes and choices regarding work effort to be different from their male counterparts. Indeed, numerous studies of the Russian labor market since 1992 document significant gender differences in employment and wages (Clarke 1999, Glinskaya and Mroz 1996, Linz 1995a 1995b 1996, Reilly 1999, Standing 1996). Moreover, given the dramatic change in Russia's economic environment, we would expect to find attitudes and choices regarding work effort made by the older generation, trained in the Soviet system and ideology, to be different from the younger generation which "came of age" during perestroika. Ignoring age and gender differences, should they prove significant, effectively undermines the successful design of an appropriate reward structure. ${ }^{6}$

What motivates Russians to work? This paper utilizes survey data collected in May/June 2000 from 1200 employees in three regions of Russia to analyze the gender and generational differences in factors influencing motivation to work. The survey results indicate that: (1) generational differences are more numerous than gender differences in terms of organizational commitment; (2) managers express a stronger

(Warsaw and Katowice) in 1996. Upchurch et al (2000) surveyed 200+ workers at a five-star hotel in St. Petersburg (no survey date given).

${ }^{6}$ This proposition is explored in detail by Busch and Bush (1978), Chasmir (1985), Dubinsky et al (1993), Fisher and Yuan (1998), Futrell (1980), Miller and Wheeler (1992), and Lacy et al (1983), among others. 


\section{William Davidson Institute Working Paper 466}

organizational commitment than workers; (3) both gender and generational differences emerge in terms of the relative importance of a particular job motivator, but in neither case are there significant differences in the overall ranking of job motivators; (4) while managers are mistaken about the importance to workers of "praise from their supervisor" and "freedom on the job," they otherwise understand what motivators are important to their employees; (5) workers are significantly more pessimistic than managers in terms of their perceptions of the likelihood of being rewarded for a job well done; (6) gender and generational differences emerge regarding the expectation of receiving rewards: women are significantly more pessimistic than their male counterparts about receiving desired rewards in response to a job well done; younger workers are significantly more optimistic than older workers.

The remainder of the paper is divided into five sections. Section 1 summarizes the research methodology and sample characteristics. Section 2 analyzes the organizational commitment among the participants in this survey. Section 3 presents survey results pertaining to the eleven job motivators, highlighting significant differences in the relative importance of each between men and women, younger and older, and workers and managers. Section 4 focuses on the expectations of receiving desired rewards for a job well done. Section 5 offers concluding remarks.

\section{Research Methodology and Sample Characteristics}

This project starts from the twofold premise that for Russian firms to be successful, labor productivity must increase relative to historical (Soviet) levels; and, for labor productivity to increase, an appropriate incentive structure must be adopted by the firm. To devise an appropriate incentive structure, information about what motivates Russians to work is essential. ${ }^{7}$

The project design involved a survey of workers and managers in three regions of Russia: Moscow, Saratov, and Taganrog. The locations were selected, in part, on the basis of previously established

\footnotetext{
${ }^{7}$ The focus of this analysis is on work effort, whether to work harder or better; not on labor force participation or job choice, that is, whether or not to work outside the home.
} 


\section{William Davidson Institute Working Paper 466}

connections and ongoing collaborative projects, ${ }^{8}$ and, in part, to investigate the extent of regional differences in attitudes toward work and perceptions of the workplace. The inclusion of Moscow, Russia's financial and political hub, enables a test of a "capital city effect." ${ }^{\prime 9}$ Taganrog, located approximately $100 \mathrm{~km}$ from Rostov in the North Caucasus region, has been documented as the "typical city" (Chichilyimov 1999, Grushin 1980, Rimashevskaya 1987). Saratov, located in the Volga region and part of Russia's "Rust Belt," continues to be a targeted site for foreign aid and investment. Local project coordinators were instructed to contact as wide a variety of workplaces as possible, and to include as many participants within the workplace as possible.

Budget constraints precluded the selection of a representative sample of workplaces by region, as well as the selection of a representative sample of workers within a participating organization.

Following the motivation literature, three broad themes are incorporated into the survey instrument: degree of organizational commitment, relative importance of select job motivators, and expectation of receiving desired reward. Two questionnaires were developed: one to be administered to workers, the second to be administered to managers. ${ }^{10}$ A core set of questions was included on both instruments. For example, both survey instruments incorporated a series of questions designed to capture two dimensions of organizational commitment: attitudes toward the workplace and satisfaction with job (Jamal 1999, Buchko et al 1998). The survey instruments differed on the questions asking about the relative importance of select job motivators. Workers were asked to identify the relative importance of a series of job motivators on a scale of 1 to 5; managers were asked to assess the relative importance to their workers of these same job motivators, using the same scale. ${ }^{11}$ This permits analysis of the extent to which managers are familiar with

\footnotetext{
${ }^{8}$ Budget constraints limited the number of locations, as well as the number of participants.

${ }^{9}$ In numerous studies of household and enterprise behavior, Moscow, described as the Disneyland of Russia, tends to lead (rather than lag) the rest of the country in terms of the magnitude and pace of changes associated with the transition process.

${ }^{10}$ The questionnaire was adopted in large part from Huddleston and Good (1999).

11 The list of eleven job motivators included in the survey instrument was developed by Huddleston and Good (1999), based on the work of Kovach (1987), Petri (1981), Silverthorne (1992), and Vroom (1964 1990), as well as on
} 


\section{William Davidson Institute Working Paper 466}

the factors which motivate their workers. Finally, the survey instrument, using the same set of job motivators, asked respondents to identify the likelihood that they would receive these rewards for a job well done.

Where the correlation between the respondents' desire for a particular reward and the expectation of receiving that reward is low, we would expect to find low labor productivity. Similarly, if participants' response patterns indicate a low level of organizational commitment, we would expect to find low labor productivity. Since the survey instrument regrettably includes no measure of workplace or individual labor productivity, it is not possible to use these data to explicitly test these two hypotheses. The questionnaire design does make it possible, however, to determine whether any gap between desired and expected reward is caused by managers not having adequate knowledge of their workers' desired motivators. Moreover, the questionnaire was designed to enable analysis of response patterns by numerous respondent characteristics: age, gender, marital status, and income level, for example, as well as by the respondent's work experience: number of years worked, and experience with unemployment.

Data collected from these 1200 Russian employees are utilized, first, to determine the extent of organizational commitment, as measured by respondent's attitude toward their workplace and degree of job satisfaction. Where organizational commitment is "above average,"12 one would expect to find a more highly motivated workforce. In such instances, there is no compelling need to develop a new reward structure.

focus groups and a pilot study Huddleston and Good conducted prior to their 1996 survey of Russian and Polish retail workers.

${ }^{12}$ Above average is defined as a response significantly higher than the neutral response $(=3)$. 


\section{William Davidson Institute Working Paper 466}

In this survey, respondents were asked a series of nine questions which focused on their perceptions about their workplace (see top panel of Table 1). For each question, respondents were given a 5-point Likert scale, where $1=$ strongly disagree and $5=$ strongly agree. Neutral responses $(=3)$ are taken to be the baseline response in terms of evaluating whether the respondent has a positive or negative attitude toward the workplace. In seven of the nine questions, the higher the score, the greater the degree of organizational commitment. Two questions, QUIT and DONOMORE, are negatively worded, and thus a lower score indicates a greater degree of organizational commitment. As seen in Table 1, participants in this survey exhibited a generally positive attitude toward their workplace. While none of the scores suggest a particularly strong organizational commitment, it does appear important to this group of respondents to feel as though they are making a contribution to their organization.

A second series of five questions placed later in the survey instrument asked respondents to identify their level of satisfaction with their job (see bottom panel of Table 1). Once again the questions used a 5-point Likert scale, where $1=$ strongly disagree, $3=$ neutral, and $5=$ strongly agree. The wording of two questions, THNKQT and ALLQUIT, was such that a lower score reflects a higher degree of job satisfaction. As seen in Table 1, respondents were more positive when describing their own level of job satisfaction (NOTSATIS, SATISFY) than when describing the level of job satisfaction of their co-workers. In neither case, however, was there a strong signal of job satisfaction.

For the fourteen variables utilized to capture the extent of organizational commitment, regression analysis is used to test for significant differences between the response patterns of workers and managers, men and women, and younger and older workers.

Data collected from the 1200 Russian employees are next used to rank the eleven job motivators in terms of their relative importance to workers (see Table 2). Among these respondents, financial compensation (PAY) and friendliness of co-workers (FRDWKRS) dominated the factors motivating work effort, followed closely by receiving respect from co-workers (RCVRESP) and having a chance to "do something that makes 


\section{William Davidson Institute Working Paper 466}

me feel good about myself as a person" (FEELGOOD). As seen in Table 2, respondents were not neutral about any of the eleven job motivators listed. Regression analysis is used to test for significant differences between men and women, and younger and older workers. A Wilcoxon signed rank test is used to determine if there is a significant difference in the overall rankings by gender or generation. A Spearman rank order correlation coefficient also is calculated for each comparison group. Perceptions of managers about the importance to their workers of these eleven job motivators are compared with workers' response patterns, with regression analysis used to identify significant differences.

Finally, by asking respondents about the likelihood (on a scale of 1 to 5 , where $1=$ not likely, and $5=$ extremely likely) of receiving a particular reward for doing their job well (see Table 3), the relative degree of optimism associated with receiving a desired reward is measured by comparing the actual response to the neutral response. As seen in Table 3, respondents were not optimistic about receiving their desired reward (EPAY) for a job well done. They were even more skeptical of receiving a promotion (EPROMO). These respondents indicated that good performance, at best, may result in a greater friendliness of co-workers (EFRDWKRS).

Where organizational commitment is "above average," and managers are fully aware of what their workers desire in terms of rewards, and where workers have a high expectation of receiving their desired reward for a job well done, there are likely to be few problems related to worker motivation. One would conclude that the reward structure in place is largely effective. This study seeks to determine if such a situation holds among the seventy-six workplaces included in this survey. Moreover, this study focuses on whether gender or age considerations need to be taken into account when designing effective reward structures.

\section{Sample description}

Two project coordinators in each city administered the questionnaires at each workplace, after having 


\section{William Davidson Institute Working Paper 466}

first secured permission to do so. ${ }^{13}$ The seventy-six participating workplaces included 35 manufacturing (heavy and light industry) organizations, 19 retail shops, 6 schools, 5 university and other institutes of higher learning, and 11 other service organizations. Project coordinators in some instances distributed questionnaires to employees in common areas of the workplace; in other instances, questionnaires were distributed in the individual shops/departments. In every instance, respondents who elected to participate were assured of anonymity and confidentiality. ${ }^{14}$ While response rates by workplace were not calculated, overall, more than $73 \%$ of the distributed questionnaires were completed.

Table 4 summarizes the basic sample characteristics. Just over $45 \%$ of the participants were located in Taganrog; some 49\% in Saratov, and nearly 6\% in Moscow. By design, workers comprised about $90 \%$ of the total number of participants.

While the mean age of the respondents was 39 years, the age distribution of the sample consists of a nearly even split between participants who were 30 years old or younger at the time the survey was conducted (28\%), between the ages of 31 and 40 years old (25\%), between the ages of 41 and 50 years old (25\%), and over 50 years old $(22 \%)$. For the purposes of this analysis, younger workers are defined as persons born after 1964. Younger workers account for $43 \%$ of the participants.

As a group, managers were significantly older than workers (44 years compared to 39 years), and earned significantly more each month (2312 rubles per month compared to 1067 rubles per month). Managers had worked at their current organization, on average, at least 14 years, compared to 10 years for workers. Managers were significantly less likely than workers to have reported a period of unemployment.

Women account for about $62 \%$ of the respondents, and $48 \%$ of the managers participating in the survey. Women comprise a somewhat greater proportion of the older workers (66\%) than the younger

\footnotetext{
${ }^{13}$ Since funds were not available to construct a representative sample of workplaces by city, project coordinators were instructed to contact and include as wide a variety of workplaces as possible.

${ }^{14}$ Individuals were given opportunity to take or decline taking the survey instrument. If taken, individuals had choice to return or not return the questionnaire.
} 


\section{William Davidson Institute Working Paper 466}

workers $(56 \%)$. Women participating in this project had significantly fewer years of education and worked significantly more years at their current organization than the men participating in this project. Women, both as workers and managers, earned significantly less, on average, than their male counterparts. Women were significantly less likely than men to have reported a period of unemployment, and significantly more likely to report their marital status as divorced. ${ }^{15}$

Average earnings varied significantly by region: in Moscow, average earnings from the respondent's primary job totaled 1722 rubles per month $(\sim 69) ;{ }^{16}$ in Saratov, 1213 rubles $(\$ 48)$; and in Taganrog, 1087 rubles $(\$ 43)$. More than $80 \%$ of those responding to the question $(n=1077)$ reported receiving $\$ 30$ or less per month from their primary job at the time the survey was conducted. ${ }^{17}$ Just under $10 \%$ reported receiving between $\$ 30$ and $\$ 60$ per month; a similar percentage reported receiving over $\$ 60$ per month. When asked about income received per month from all jobs which the respondent held at the time of the survey: $36 \%$ reported receiving $\$ 30$ or less from all their jobs; 39\% reported receiving between $\$ 30$ and $\$ 60$ per month; $11 \%$ reported receiving between $\$ 60$ and $\$ 90$ per month; and 14\% reported receiving over $\$ 90$ per month.

In terms of work experience, nearly $20 \%$ of the participants reported working less than 2 years at their current place of employment; 47\% reported working between 2 and 10 years at their current place of employment; 15\% reported working between 11 and 20 years at their current workplace; and 19\% reported working more than 20 years at their current place of employment. Fewer than one-in-four participants responding to the question ( $\mathrm{n}=1146)$ reported experiencing a period of unemployment.

The remainder of the paper utilizes data collected from these respondents to evaluate gender and age differences in the relative importance of organizational commitment, job motivators, and the expectation of

\footnotetext{
15 Just over $62 \%$ of the survey participants were married at the time the questionnaire was administered; $13 \%$ reported themselves as divorced; $21 \%$ single; and the remainder selected "widowed" or "other."

${ }^{16}$ The question asked respondents to report they monthly wage at the time. At the time, the exchange rate was approximately 25 rubles per $\$ 1$. Income categories were created to put their responses into a broader perspective.

${ }^{17}$ In many studies, absolute poverty is defined as incomes equal to \$1 per day. See for example, UNDP's Poverty in Transition (1998).
} 


\section{William Davidson Institute Working Paper 466}

receiving a reward for a job well done (or additional work effort).

\section{Organizational Commitment}

Organizational commitment, measured here as positive attitudes about one's workplace and expressions of job satisfaction, tends to reflect a good fit between an individual's abilities and his/her work environment (Jamal 1999). In studies conducted in the U.S., organizational commitment is shown to be positively correlated to age, job level, job tenure, and satisfaction associated with one's job, pay, promotion opportunities, supervisor, and co-workers (Mowday et al 1982, Mathieu and Zajac 1990).

Do Russians express a positive attitude toward their place of work and/or about their job? For the fourteen questions designed to capture the extent of organizational commitment (see Table 5), response patterns varied by gender, generation, and by job status (worker versus manager).

In the first series of questions, respondents were asked to select the extent to which they agreed with a particular statement about their attitude toward their workplace. ${ }^{18}$ As seen in the first columns of Table 5, both managers and workers feel most strongly about the importance of making a contribution (CONTRIB); ${ }^{19}$ neither report thinking often of leaving the company for good (QUIT). The significant differences between the response patterns of managers and workers for eight of the nine questions captures the fact that the managers participating in this survey were significantly more positive than workers in terms of their perceptions of their workplace. ${ }^{20}$ Buchko et al (1998), using a survey conducted after $1992^{21}$ of 180 managers and workers employed by a large Russian manufacturing firm located not far from Samara, ${ }^{22}$ find that job status does not

\footnotetext{
18 A neutral response (=3) is used as the baseline, with scores above 3 reflecting a positive attitude and scores below 3 reflecting a negative attitude. For two questions, QUIT and DONOMORE, where the question is negatively worded, lower scores reflect positive attitude.

${ }^{19}$ Ivancevich et al (1992) found that Russian workers exhibit a greater work involvement than their American counterparts, more frequently taking work home or thinking about their work outside of their workplace.

${ }^{20}$ This result is consistent with findings of Cohen and Lowenberg (1990) and Angle and Perry (1983).

${ }^{21}$ No date is given regarding when the survey was conducted. References used in the article suggest the survey was likely conducted in 1996 or 1996.
} 


\section{William Davidson Institute Working Paper 466}

generate significantly different results with respect to organizational commitment. Their result may focus more on company policy or company conditions than apply to a broader population, however.

Gender differences among the participants in this project emerge for three of the nine variables regarding attitudes about the workplace. ${ }^{23}$ That is, women are less likely than men to think about changing companies for a marginal increase in pay (NOTCHGJB) or to recommend a close friend to join the company (RECOMMEN); but are more likely than men to be pleased by knowing that their work has made a contribution to the good of the organization (CONTRIB). Focus groups comprised of faculty and students at Taganrog State University for Radio Engineering (TSURE) in February 2001 underscored this result. ${ }^{24}$ They attributed the result to the role that Russian women have traditionally held as the primary care-giver and secondary income-earner in the household. In their view, a Russian woman's job choice is likely to be more restricted by location or the need for flexible hours, for example, than would be a comparable job choice decision made by a Russian man. The general importance of socialization in explaining gender differences in reward distribution is described by Stake (1983) and Greenberg and Leventhal (1976).

Younger workers tend not to exhibit a strong degree of organizational commitment, as measured by attitude toward their workplace. ${ }^{25}$ Younger employees (those born after 1964) were significantly less likely to

\footnotetext{
${ }^{22}$ Samara, located in Volga Region, was a "closed" city until 1992 due to the high concentration of military production.

${ }^{23}$ See Kirkcaldy and Athanasou (1999) for discussion of how age and gender shape perceptions of workplace climate. To date, no studies of which focus on the motivation of Russian workers includes analyses of gender differences.

${ }^{24}$ All in all, 4 focus group sessions were conducted at TSURE: one with eight faculty members, and three with 5-8 students in each group. Women accounted for the majority of participants in the focus groups. Participants were given the survey instrument which contained 8 sets of questions, plus a number of single questions which focused on respondent characteristics. The focus group participants were asked to write down a list of questions which they thought would generate different response patterns between men and women. After turning in their written responses, participants discussed their choices and explained their reasoning.

${ }^{25}$ This finding is consistent with studies conducted in the U.S., where organizational commitment tends to be positively correlated with age and job tenure. See for example, Angle and Perry (1961), Hrebiniak (1974), Meyer and Allen (1984), and Mowday et al (1979).
} 


\section{William Davidson Institute Working Paper 466}

feel a part of the organization (PARTORG); significantly less likely to care whether they were making a contribution to the organization (GOODJOB); and significantly less likely to feel like their work has made a contribution to the good of the organization (CONTRIB). Generational differences all but disappear when "years worked at organization" is held constant, however.

A second series of questions placed later in the survey instrument asked respondents to identify their level of job satisfaction. Overall, when reporting their own level of job satisfaction, respondents were generally, but not strongly, positive (NOTSATIS, THNKQT, SATISFY). When responding to questions about the level of job satisfaction experienced by others, respondents were somewhat negative (ALLSATIS, ALLQUIT). Significant differences surface between managers and workers with regard to level of job satisfaction (see bottom panel of Table 5). Not surprisingly, managers expressed a higher level of job satisfaction than workers. Moreover, managers were significantly more likely than workers to think the majority of others were satisfied with their job. Both managers and workers were equally likely to disagree that co-workers thought often of quitting.

While there were no gender differences emerging in the response patterns, a significant generational difference is evident. Younger respondents were significantly less satisfied with their job than older respondents. ${ }^{26}$ There were no generational differences in the perception of the job satisfaction levels of coworkers.

It is easier to motivate work effort among employees who have a positive attitude toward their workplace and are satisfied with their job than among employees who have a negative attitude about both workplace and job. Among the Russians participating in this project, managers exhibited a stronger organizational commitment than workers; a result consistent with studies of organizational commitment

\footnotetext{
${ }^{26}$ Studies conducted in the U.S. identify 5 dimensions of job satisfaction: pay, promotion, supervisors, co-workers, and the work itself (Mathieu and Zajac 1990, Price and Mueller 1986, Smith et al 1969). The results generally support a positive correlation between age and these variables. Thus, the result that younger Russian workers are less satisfied with their job than older workers is consistent with previous studies.
} 


\section{William Davidson Institute Working Paper 466}

conducted in the United States. Workers express rather weakly positive attitudes toward their workplace, and while generally not dissatisfied with their job, do not offer a ringing endorsement of their organizational commitment. Holding constant the number of years worked at the organization, women and younger workers tend to be the least satisfied with their workplace and job.

\section{Job Motivators}

What motivates Russians to work? Huddleston and Good (1999) report results derived from a survey of 675 Russian and Polish retail workers conducted in 1996 which show the relative ranking of eleven job motivators (rewards). Among their respondents, pay and friendliness of co-workers dominated the motivators (mean value $=4.8$ for both, on a scale of 1 to 5 ), with respect and job security following in the second and third positions (4.6 and 4.5, respectively).

This study utilizes the same eleven job motivators employed by Huddleston and Good (1999), asking respondents to select how important each factor is to them (see Table 6). Significant gender differences in the response patterns of the participants in this survey emerge in more than half of the cases. Women are more likely than men to say that pay is very important (PAY), the chance to do something that makes them feel good as a person is very important (FEELGOOD), job security is very important (JOBSECR), receiving respect from co-workers is very important (RCVRESP), receiving praise from supervisor is very important (SUPRPRZ), and the friendliness of co-workers is very important (FRDWKRS). Individually, each of these motivators is more important to women than to men; that is, the mean value is significantly higher. However, the relative ranking of these job motivators from most important to least important, based on mean response values, is not significantly different between the men and women participating in this study. ${ }^{27}$

That women feel more strongly than men about the importance of seven of these eleven job

\footnotetext{
${ }^{27}$ Two tests were conducted to establish this result. First, the Wilcoxon signed rank test was used to determine if there was a significant difference in the relative ranking by men and women. The first procedure involved pairing the rankings of these eleven variables; the second procedure involved using the mean response values. In neither instance was it possible to reject the null hypothesis that the rankings were the same. Second, the Spearman rank order correlation coefficient was calculated. The results of the test indicate no significant difference between men and women in the ranking of the relative importance of these eleven job motivators.
} 


\section{William Davidson Institute Working Paper 466}

motivators was not surprising to members of the focus groups that were conducted at TSURE in February 2001. They viewed Russian women as somewhat more willing to express extreme views; describing this characteristic as being more honest. Russian men were characterized as being more reserved. That the overall ranking of the relative importance of all eleven motivators was the same for both men and women also came as no surprise to the younger members of the focus groups. In their view, it reaffirmed the equality of men and women in the workplace.

These data also highlight a generational difference in response patterns regarding the relative importance of the eleven job motivators used in this study. Younger respondents placed a higher value than did older respondents on the opportunity to develop skills and abilities (SKLDVLP), getting a promotion or better job (PROMO), and the chance to accomplish something worthwhile (ACCMPL). Younger respondents placed a lower value on the amount of pay received (PAY), the amount of security associated with the job, the respect received from co-workers (RCVRESP), and the friendliness of co-workers (FRDWKRS) than did older respondents. Both generations agreed that pay was at the top of the ranking of these job motivators in terms of relative importance, and praise from supervisor was at the bottom of the ranking. Overall, according to the Spearman rank order correlation test, there is no significant difference in the rank order emerging from the younger and older generations.

Do the perceptions of managers about the relative importance to their workers of the eleven job motivators included in this study match the response patterns of the workers? Huddleston and Good (1999) compare the importance of the eleven rewards as reported by workers with managers' perceptions of the importance to their workers of these rewards. Their results indicate only one significant difference between managers' and employees' response patterns: “praise from supervisor was perceived by managers to be more important than employees actually rated it" (p. 389).

Table 7 reports the response patterns of managers and workers participating in this study. In only two instances are there significant differences between managers' perceptions and workers' responses. Not 


\section{William Davidson Institute Working Paper 466}

surprisingly, managers think workers will value praise from their supervisors (SUPRPRZ) more than workers actually report doing so. Managers' perceptions do not coincide with workers' responses regarding the importance of having some freedom associated with the job (FREEJOB) - managers perceive this to be less important than workers report it to be. There is no significant difference between managers and workers in the rankings of relative importance, however. ${ }^{28}$

These data indicate that while there are gender and generational differences in the degree of importance attached to a particular job motivator, the overall ranking of the importance of job motivators is generally similar across gender and generation among the 1200 participants in this project. Moreover, the perceptions of managers about the relative importance of select job motivators is generally in line with the actual responses of workers.

\section{Expectations of Receiving Desired Reward}

What causes workers to initiate or sustain a given level of performance? Petri (1981) suggests that in the workplace individuals are motivated by the expectation that their behavior or actions will produce results which in turn will generate desired rewards. Vroom (1964) posits that the degree of motivation is directly related to the expectation of receiving a reward and the overall attractiveness of the reward. To what extent do workers expect to be rewarded for a job well done? Cox (1985) reports the results of a survey of American workers who were asked: "Do you think that if you improve your productivity, and your personal contribution to your business, you will benefit, personally, from that productivity?" More than $85 \%$ of the respondents said "no." Silverthorne (1992) demonstrates variation across countries (US, China, Russia) in the relative importance of select job motivators.

Do Russian workers expect to be rewarded for a job well done? Do they expect to receive the rewards they value most highly? Participants in this project were given the same eleven job motivators used in the previous series of questions, and asked about the likelihood (on a scale of 1 to 5 , where $1=$ not likely, and

\footnotetext{
${ }^{28}$ Using both the Wilcoxon signed rank test and the Spearman rank order correlation test, it was not possible to reject the hypothesis that the rankings by managers and workers are the same.
} 


\section{William Davidson Institute Working Paper 466}

$5=$ extremely likely) of receiving a particular reward for doing their job well. As seen in Tables 2 and 3 , in every case, respondents' expectations of receiving the eleven rewards were not in line with the importance placed on them. That is, in every case, the mean score reflecting the perception of the likelihood of receiving the reward was well below the mean score indicating the desirability of that same reward. This result coincides with the findings of Huddleston and Good (1999); both Russian and Polish retail workers generated significantly lower mean values on the expectation of receiving a reward in comparison to the mean value associated with the importance of the reward.

Table 8 provides a breakdown of the response patterns by job status, gender and generation. As seen in the first panel, managers are significantly more optimistic than workers about receiving rewards for a job well done; mean scores for managers are higher for every variable than for workers. However, the rank ordering of these variables from least expected to most expected for workers and manager is not significantly different; the Spearman coefficient is 0.918.

Women consistently report lower expectations of receiving a desired reward despite the quality of their work. In five of the eleven cases (EPAY, ELEARN, EPROMO, EACCMPL, EFREEJOB), the difference between men and women is significant (see Table 8). Once again, however, there is no significant difference between the rankings of men and women in terms of their expectation of receiving a particular reward; the Spearman coefficient is 0.964 .

Significant generational differences in the expectation of receiving rewards for a job well done are evident. As seen in Table 8, younger workers are much more optimistic about receiving rewards than older workers. However, in terms of relative ranking, there is no significant generational difference in the rank order of expectation; the Spearman coefficient is 0.936.

These results uniformly support the proposition that, to the extent that low labor productivity continues to exist in Russia, it likely stems in no small part from the lack of an appropriate reward structure. For each of the job motivators used in this analysis, the expectation of receiving a desired reward is 


\section{William Davidson Institute Working Paper 466}

significantly lower than the relative importance placed on it. In short, Russian workers are not receiving what they want.

\section{Summary and Conclusions}

What motivates Russians to work? This paper utilizes survey data collected in May/June 2000 from 1200 employees in three regions of Russia to analyze the gender and generational differences in factors influencing motivation to work. Five main results emerge. First, Russians are not significantly different from their counterparts in the United States in terms of what is important to them at their place of work. Organizational commitment, however, emerges as only weakly positive among Russian workers; among managers the signal is much stronger. Second, there is little confusion on the part of managers regarding what is important to their workers. Managers' only mistake was to think workers valued their praise. Third, Russian workers have very low expectations of receiving any reward which they desire. This result, similar to results generated by American workers in the mid-1980s, is especially strong among the women and the older generation of workers participating in this survey. Fourth, gender differences involve the relative importance of particular motivators rather than differences in the ranking of motivators from most important to least important. That is, the Russian women participating in this project tended to express stronger feelings toward each of the motivators than the men, but the women did not rank order the motivators any differently than the

men. Fifth, in many instances, generational differences disappeared when work experience was held constant. Age was only significant when expectation of receiving a particular reward was involved.

What is to be done regarding the design of appropriate reward structures? Russian workers are clearly motivated by financial rewards. They also place a premium on certain conditions of their workplace: the friendliness and respect of co-workers, the ability to develop skills, and the opportunity to make a contribution. If a firm's financial conditions preclude additional (or timely) payments to workers, these data suggest that alternative "rewards" might compensate. Huddleston and Good (1999) suggest formal and informal training programs and employee development seminars, as well as social activities. Most importantly, 


\section{William Davidson Institute Working Paper 466}

these data underscore the fact that Russian workers' hold very low expectations of receiving desired rewards. Under such conditions, motivation is seriously curtailed, and labor productivity is likely to remain low. 
William Davidson Institute Working Paper 466

\section{TABLE 1: Organizational Commitment}

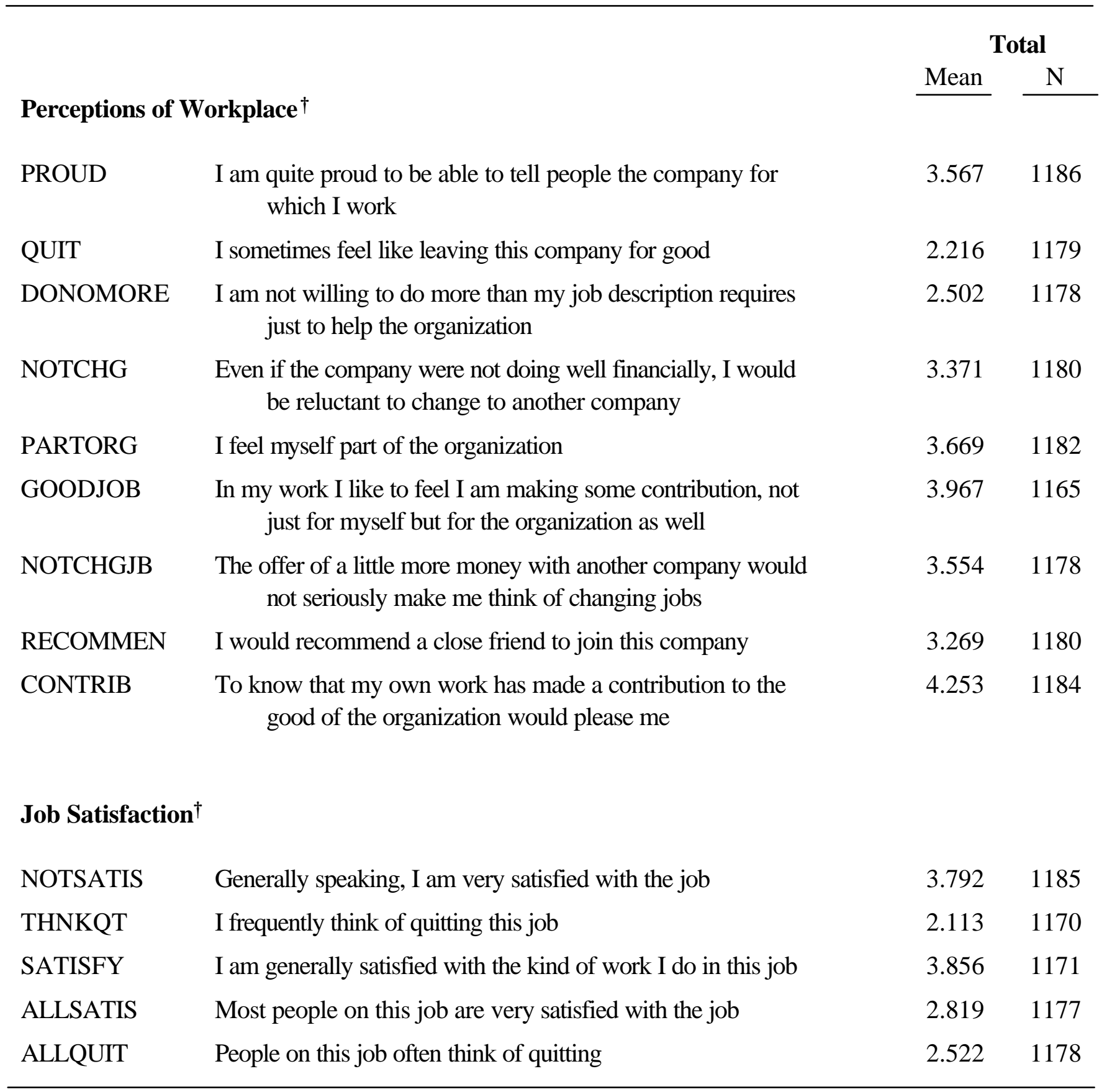

†Coded as: 1 = strongly disagree; $3=$ neutral; $5=$ strongly agree 
William Davidson Institute Working Paper 466

\section{TABLE 2: Job Motivators}

\begin{tabular}{|c|c|c|c|}
\hline \multirow{2}{*}{\multicolumn{4}{|c|}{ (n) }} \\
\hline & & Mean & $\mathrm{N}$ \\
\hline PAY & The amount of pay I receive & 4.742 & 1195 \\
\hline FEELGOOD & $\begin{array}{l}\text { The chance I have to do something that makes } \\
\text { me feel good about myself as a person }\end{array}$ & 4.281 & 1183 \\
\hline SKLDVLP & The opportunity to develop my skills and abilities & 4.530 & 1189 \\
\hline JOBSECR & The amount of job security I have & 4.380 & 1184 \\
\hline LEARN & The chance I have to learn new things & 4.428 & 1188 \\
\hline PROMO & The chance at getting a promotion or better job & 4.195 & 1173 \\
\hline ACCMPL & The chance I have to accomplish something worthwhile & 4.363 & 1177 \\
\hline FREEJOB & The amount of freedom I have on my job & 3.947 & 1174 \\
\hline RCVRESP & The respect I receive from the people I work with & 4.572 & 1182 \\
\hline SUPRPRZ & The praise I receive from my supervisor & 3.843 & 1172 \\
\hline FRDWKRS & The friendliness of the people I work with & 4.706 & 1187 \\
\hline
\end{tabular}

${ }^{\dagger}$ Coded as: $1=$ not important; $3=$ neutral; $5=$ very important 
William Davidson Institute Working Paper 466

TABLE 3: Expectation of Receiving Reward

\begin{tabular}{llll}
\hline & & \multicolumn{2}{c}{ Total } \\
How likely is it that I will receive these rewards for doing my job well? ${ }^{\dagger}$ & Mean & \\
\cline { 2 - 3 } EPAY & I will receive bonus or pay increase & 2.734 & 1186 \\
EFEELGD & I will feel better about myself as a person & 3.695 & 1175 \\
ESKLDVLP & I will have opportunity to develop my skills and abilities & 3.622 & 1165 \\
EJOBSECR & I will have better job security & 3.478 & 1177 \\
ELEARN & I will be given a chance to learn new things & 3.255 & 1154 \\
EPROMO & I will be promoted or get a better job & 2.453 & 1162 \\
EACCMPL & I will feel that I accomplished something worthwhile & 3.577 & 1176 \\
EFREEJOB & I will have more freedom on my job & 2.863 & 1168 \\
ERCVRESP & I will be respected by the people I work with & 3.740 & 1175 \\
ESUPRPRZ & My supervisor will praise me & 3.207 & 1167 \\
EFRDWKRS & The people I work with will be friendly to me & 3.802 & 1180 \\
\hline
\end{tabular}

†Coded as: 1 = not likely; 3 = neutral; 5 = extremely likely 
TABLE 4: Sample Characteristics

\begin{tabular}{|c|c|c|c|c|c|c|c|c|}
\hline \multirow{3}{*}{$\begin{array}{l}\text { Number of Respondents } \\
\text { Total }\end{array}$} & \multicolumn{2}{|c|}{ Moscow } & \multicolumn{2}{|c|}{ Saratov } & \multicolumn{2}{|c|}{ Taganrog } & \multicolumn{2}{|l|}{ Total } \\
\hline & \multicolumn{2}{|c|}{ Frequency $\%$} & \multicolumn{2}{|c|}{ Frequency $\%$} & \multicolumn{2}{|c|}{ Frequency $\%$} & \multirow{2}{*}{$\begin{array}{c}\text { Frequency } \\
1200\end{array}$} & \multirow{2}{*}{$\begin{array}{c}\% \\
100\end{array}$} \\
\hline & 69 & 5.8 & 585 & 48.8 & 546 & 45.5 & & \\
\hline Workers & 69 & 6.4 & 523 & 48.5 & 486 & 45.1 & 1078 & 100 \\
\hline Managers & 0 & 0.0 & 62 & 49.2 & 60 & 50.8 & 122 & 100 \\
\hline Men & 33 & 7.3 & 188 & 41.7 & 230 & 51.0 & 453 & 100 \\
\hline Women & 36 & 5.0 & 383 & 52.7 & 307 & 42.3 & 726 & 100 \\
\hline Younger & 19 & 1.7 & 233 & 44.7 & 269 & 51.6 & 521 & 100 \\
\hline Older & 50 & 7.4 & 352 & 51.8 & 277 & 40.8 & 679 & 100 \\
\hline Respondent Characteristic & Mo & & Sar & & Tagaı & & Total & \\
\hline Mean Response & Mean & $\mathrm{N}$ & Mean & $\mathrm{N}$ & Mean & $\mathrm{N}$ & Mean & $\mathrm{N}$ \\
\hline Year born & 1952 & 69 & 1960 & 582 & 1963 & 528 & 1961 & 1179 \\
\hline Years schooling & 16.3 & 65 & 15.0 & 571 & 14.9 & 534 & 15.0 & 1170 \\
\hline Income [main job] (rubles) & 1722 & 69 & 1213 & 567 & 1087 & 441 & 1194 & 1077 \\
\hline Income [all jobs] (rubles) & 2270 & 69 & 1374 & 555 & 1216 & 434 & 1368 & 1058 \\
\hline Years@ current workplace & 18.8 & 69 & 11.1 & 580 & 8.6 & 530 & 10.4 & 1179 \\
\hline Number jobs held & 1.2 & 69 & 1.2 & 506 & 1.2 & 472 & 1.2 & 1047 \\
\hline
\end{tabular}


TABLE 5: Organizational Commitment: Occupation, Gender, and Age ${ }^{1}$

Perceptions of Workplace ( 1 = strongly disagree; 3 = neutral; 5 = strongly agree $)$

\begin{tabular}{|c|c|c|c|c|c|c|c|c|c|c|c|c|}
\hline & \multicolumn{2}{|c|}{ Managers } & \multicolumn{2}{|c|}{ Workers } & \multicolumn{2}{|c|}{ Women } & \multicolumn{2}{|c|}{ Men } & \multicolumn{2}{|c|}{ Younger } & \multicolumn{2}{|c|}{ Older } \\
\hline & Mean & $\mathrm{N}$ & Mean & $\mathrm{N}$ & Mean & $\mathrm{N}$ & Mean & $\mathrm{N}$ & Mean & $\mathrm{N}$ & Mean & $\mathrm{N}$ \\
\hline PROUD & $4.026^{*}$ & 122 & 3.512 & 1064 & 3.556 & 719 & 3.567 & 448 & 3.613 & 512 & 3.533 & 674 \\
\hline QUIT & $1.697 *$ & 122 & 2.276 & 1057 & 2.222 & 716 & 2.212 & 444 & 2.248 & 511 & 2.192 & 668 \\
\hline DONOMORE & $2.157 *$ & 121 & 2.542 & 1057 & 2.459 & 714 & 2.573 & 445 & 2.535 & 512 & 2.478 & 668 \\
\hline NOTCHG & $3.705^{*}$ & 122 & 3.332 & 1058 & 3.373 & 715 & 3.368 & 446 & 3.137 & 510 & 3.549 & 670 \\
\hline PARTORG & $3.900 *$ & 120 & 3.643 & 1062 & 3.664 & 718 & 3.679 & 445 & $3.557 *$ & 508 & 3.754 & 674 \\
\hline GOODJOB & $4.267^{*}$ & 120 & 3.933 & 1045 & 3.982 & 707 & 3.945 & 439 & $3.787^{*}$ & 502 & 4.104 & 663 \\
\hline NOTCHGJB & $3.844 *$ & 122 & 3.521 & 1056 & $3.489 *$ & 714 & 3.667 & 445 & 3.510 & 510 & 3.588 & 668 \\
\hline RECOMMEN & 3.617 & 120 & 3.229 & 1060 & $3.200 *$ & 716 & 3.366 & 445 & 3.316 & 513 & 3.232 & 667 \\
\hline CONTRIB & $4.516^{*}$ & 122 & 4.223 & 1062 & $4.299 *$ & 719 & 4.181 & 446 & $4.142 *$ & 513 & 4.338 & 671 \\
\hline
\end{tabular}

Job Satisfaction $(1=$ strongly disagree; 3 = neutral; 5 = strongly agree $)$

\begin{tabular}{|c|c|c|c|c|c|c|c|c|c|c|c|c|}
\hline & \multicolumn{2}{|c|}{ Managers } & \multicolumn{2}{|c|}{ Workers } & \multicolumn{2}{|c|}{ Women } & \multicolumn{2}{|c|}{ Men } & \multicolumn{2}{|c|}{ Younger } & \multicolumn{2}{|c|}{ Older } \\
\hline & Mean & $\mathrm{N}$ & Mean & $\mathrm{N}$ & Mean & $\mathrm{N}$ & Mean & $\mathrm{N}$ & Mean & $\mathrm{N}$ & Mean & $\mathrm{N}$ \\
\hline NOTSATIS & $4.106^{*}$ & 122 & 3.756 & 1063 & 3.766 & 717 & 3.835 & 449 & $3.713^{*}$ & 512 & 3.853 & 673 \\
\hline THNKQT & $1.803^{*}$ & 122 & 2.150 & 1048 & 2.100 & 710 & 2.131 & 441 & $2.234^{*}$ & 508 & 2.021 & 662 \\
\hline SATISFY & $4.190^{*}$ & 121 & 3.818 & 1050 & 3.860 & 710 & 3.848 & 442 & $3.726 *$ & 507 & 3.956 & 664 \\
\hline ALLSATIS & $3.050 *$ & 120 & 2.793 & 1057 & 2.802 & 711 & 2.837 & 447 & 2.872 & 514 & 2.778 & 663 \\
\hline ALLQUIT & 2.392 & 120 & 2.537 & 1058 & 2.529 & 712 & 2.503 & 447 & 2.541 & 514 & 2.508 & 664 \\
\hline
\end{tabular}

${ }^{1}$ Younger generation includes respondents born after 1964; older generation includes respondents born before 1965.

*Significant at $1 \%$. 


\section{TABLE 6: Job Motivators: Relative Ranking by Gender and Age}

What is important to me at my workplace? $(1=$ not important; $3=$ neutral; $5=$ very important $)$

\begin{tabular}{|c|c|c|c|c|c|c|c|c|c|c|c|c|}
\hline & \multicolumn{3}{|c|}{ Women } & \multicolumn{3}{|c|}{ Men } & \multicolumn{3}{|c|}{ Younger } & \multicolumn{3}{|c|}{ Older } \\
\hline & Mean & $\mathrm{N}$ & Rank & Mean & $\mathrm{N}$ & Rank & Mean & $\mathrm{N}$ & Rank & Mean & $\mathrm{N}$ & Rank \\
\hline PAY & $4.803^{*}$ & 725 & 1 & 4.634 & 449 & 1 & $4.680^{*}$ & 518 & 1 & 4.790 & 667 & 1 \\
\hline FEELGOOD & $4.399 *$ & 714 & 7 & 4.092 & 449 & 7 & 4.268 & 511 & 9 & 4.292 & 672 & 7 \\
\hline SKLDVLP & 4.525 & 718 & 4 & 4.546 & 450 & 3 & $4.600^{*}$ & 515 & 3 & 4.478 & 674 & 4 \\
\hline JOBSECR & $4.527 *$ & 715 & 5 & 4.124 & 449 & 8 & $4.312 *$ & 512 & 8 & 4.431 & 672 & 6 \\
\hline LEARN & 4.443 & 719 & 6 & 4.404 & 450 & 6 & 4.487 & 515 & 5 & 4.383 & 673 & 5 \\
\hline PROMO & $4.270 *$ & 711 & 9 & 4.079 & 443 & 9 & $4.394^{*}$ & 510 & 7 & 4.042 & 663 & 9 \\
\hline ACCMPL & 4.374 & 711 & 8 & 4.338 & 446 & 5 & $4.517^{*}$ & 509 & 4 & 4.246 & 668 & 8 \\
\hline FREEJOB & 3.956 & 706 & 11 & 3.917 & 448 & 10 & 3.925 & 510 & 10 & 3.964 & 664 & 10 \\
\hline RCVRESP & $4.663 *$ & 715 & 3 & 4.414 & 447 & 4 & $4.472 *$ & 511 & 6 & 4.648 & 671 & 3 \\
\hline SUPRPRZ & $4.024^{*}$ & 706 & 10 & 3.529 & 446 & 11 & 3.788 & 506 & 11 & 3.886 & 666 & 11 \\
\hline FRDWKRS & $4.771 *$ & 717 & 2 & 4.598 & 450 & 2 & $4.616^{*}$ & 513 & 2 & 4.774 & 674 & 2 \\
\hline
\end{tabular}

*Significant at $1 \%$. 
William Davidson Institute Working Paper 466

TABLE 7: Job Motivators: Relative Ranking by Managers and Workers

What is important to my workers/me at my workplace?

$(1=$ not important; $3=$ neutral $; 5=$ very important $)$

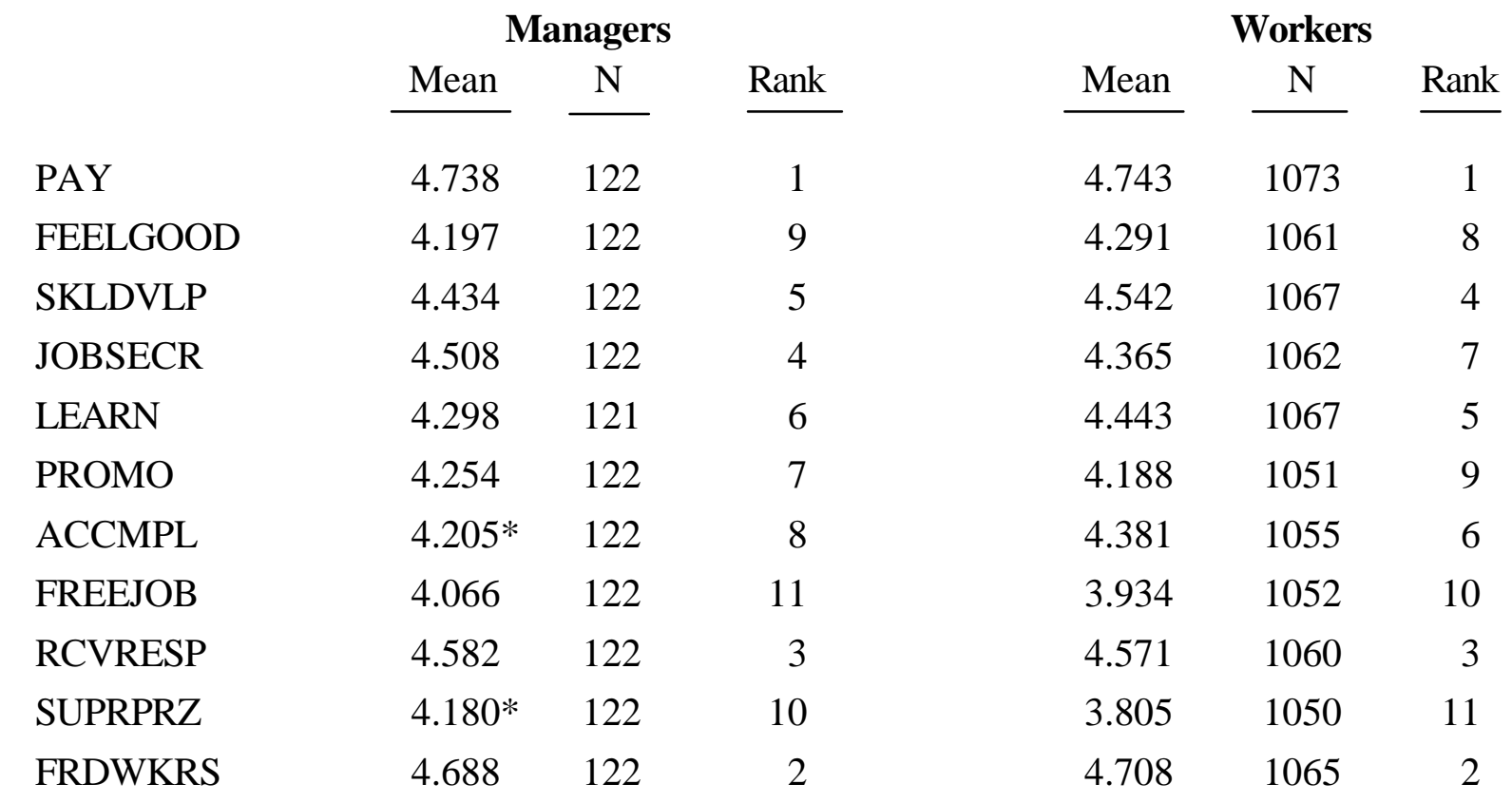

*Significant at $1 \%$. 
TABLE 8: Expectation of Receiving Rewards: Relative Ranking by Occupation, Gender and Age

How likely is it that I will receive these rewards for doing my job well? $(1=$ not likely; $3=$ neutral; $5=$ extremely likely $)$

\begin{tabular}{|c|c|c|c|c|c|c|c|c|c|c|c|c|}
\hline & \multicolumn{3}{|c|}{ Managers } & \multicolumn{3}{|c|}{ Workers } & & & & & & \\
\hline & Mean & $\mathrm{N}$ & Rank & Mean & $\mathrm{N}$ & Rank & & & & & & \\
\hline EPAY & $3.149^{*}$ & 121 & 10 & 2.787 & 1065 & 10 & & & & & & \\
\hline EFEELGD & $4.049^{*}$ & 122 & 5 & 3.654 & 1053 & 3 & & & & & & \\
\hline ESKLDVLP & $4.117^{*}$ & 120 & 1 & 3.565 & 1045 & 4 & & & & & & \\
\hline EJOBSECR & $3.959 *$ & 121 & 6 & 3.423 & 1056 & 6 & & & & & & \\
\hline ELEARN & $3.636^{*}$ & 121 & 7 & 3.210 & 1033 & 7 & & & & & & \\
\hline EPROMO & $2.857^{*}$ & 119 & 11 & 2.406 & 1043 & 11 & & & & & & \\
\hline EACCMPL & $4.076^{*}$ & 118 & 4 & 3.522 & 1058 & 5 & & & & & & \\
\hline EFREEJOB & $3.308^{*}$ & 120 & 9 & 2.812 & 1048 & 9 & & & & & & \\
\hline ERCVRESP & $4.083^{*}$ & 121 & 2 & 3.701 & 1054 & 2 & & & & & & \\
\hline ESUPRPRZ & $3.458^{*}$ & 118 & 8 & 3.179 & 1049 & 8 & & & & & & \\
\hline \multirow[t]{3}{*}{ EFRDWKRS } & $4.082^{*}$ & 122 & 3 & 3.770 & 1058 & 1 & & & & & & \\
\hline & \multicolumn{3}{|c|}{ Women } & \multicolumn{3}{|c|}{ Men } & \multicolumn{3}{|c|}{ Younger } & \multicolumn{3}{|c|}{ Older } \\
\hline & Mean & $\mathrm{N}$ & Rank & Mean & $\mathrm{N}$ & Rank & Mean & $\mathrm{N}$ & Rank & Mean & $\mathrm{N}$ & Rank \\
\hline EPAY & $2.660^{*}$ & 719 & 10 & 2.862 & 448 & 10 & $2.945^{*}$ & 513 & 10 & 2.754 & 673 & 10 \\
\hline EFEELGD & 3.694 & 710 & 3 & 3.693 & 446 & 4 & 3.750 & 512 & 3 & 3.653 & 663 & 3 \\
\hline ESKLDVLP & 3.568 & 702 & 4 & 3.689 & 444 & 5 & $3.816^{*}$ & 507 & 2 & 3.473 & 658 & 5 \\
\hline EJOBSECR & 3.418 & 711 & 6 & 3.557 & 447 & 6 & $3.655^{*}$ & 510 & 6 & 3.343 & 667 & 6 \\
\hline ELEARN & $3.169^{*}$ & 697 & 8 & 3.363 & 438 & 7 & $3.433^{*}$ & 503 & 7 & 3.117 & 651 & 7 \\
\hline EPROMO & $2.328^{*}$ & 701 & 11 & 2.657 & 443 & 11 & $2.741 *$ & 506 & 11 & 2.230 & 656 & 11 \\
\hline EACCMPL & $3.463^{*}$ & 712 & 5 & 3.748 & 445 & 3 & $3.675^{*}$ & 511 & 5 & 3.502 & 665 & 4 \\
\hline EFREEJOB & $2.750^{*}$ & 705 & 9 & 3.047 & 444 & 9 & $3.039 *$ & 510 & 9 & 2.726 & 658 & 9 \\
\hline ERCVRESP & 3.721 & 713 & 2 & 3.766 & 444 & 2 & 3.738 & 512 & 4 & 3.742 & 663 & 2 \\
\hline ESUPRPRZ & 3.231 & 709 & 7 & 3.164 & 439 & 8 & $3.417 *$ & 504 & 8 & 3.048 & 663 & 8 \\
\hline EFRDWKRS & 3.825 & 713 & 1 & 3.754 & 448 & 1 & $3.819^{*}$ & 515 & 1 & 3.789 & 665 & 1 \\
\hline
\end{tabular}

*Significant at $1 \%$. 
William Davidson Institute Working Paper 466

References

Adler, N.J. 1983. "Cross Cultural Management Research: The Ostrich and the Trend," vol 8, Academy of Management Review, pp. 226-232.

Adler, N.J. 1990. International Dimensions of Organizational Behavior (Boston: Kent Publishing).

Aghion, Philippe and Wendy Carlin. 1996. "Restructuring Outcomes and the Evolution of Ownership Patterns in Central and Eastern Europe," Economics of Transition, vol 4 no 2 (October), pp. 371-388.

Anderson, James H, Georges Korsun, and Peter Murrell. 1999. "Ownership, Exit, and Voice After Mass Privatization: Evidence from Mongolia," Economics of Transition, vol 7 no 1 (March), pp. 215-243.

Angle, H.L. and J.L. Perry. 1983. "Organizational Commitment - Individual and Organizational Influence,” vol 10, Work and Occupations, pp. 123-146.

Barberis, Nicholas, Maxim Boycko and Andrei Shliefer. 1996. "How Does Privatization Work? Evidence from the Russian Shops," Journal of Political Economy, vol 104, no 4 (August), pp. 764-790.

Bartolome, F. and P.A. Evans. 1979. "Professional Lives Versus Private Lives: Shifting Patterns in Managerial Commitment," vol 7, no 4 Organizational Dynamics , pp. 2-29.

Berliner, Joseph S. 1957. Factory and Manager (Cambridge: Harvard University Press).

Blasi, Joseph et al. 1997. Kremlin Kapitalism: Privatizing the Russian Economy (Ithaca NY: Cornell University Press).

Brada, Josef. 1996. "Privatization is Transition - Or is it?" vol 10, no 2 Journal of Economic Perspectives (Spring), pp. 67-86.

Brady, Rose. 1999. Kapitalizm: Russia's Struggle to Free its Economy (New Haven: Yale University Press).

Broadman, Harry G. 2000. "Reducing Structural Dominance and Entry Barriers in Russian Industry,"

Review of Industrial Organization, vol 17, no 2 (September), pp. 155-176.

Buchko, Aaron A, Laurence G. Weinzimmer, and Alexander V. Sergeyev. 1998. "Effect of Cultural Context on the Antecedents, Correlates and Consequences of Organizational Commitment: A Study of Russian Workers," vol 43, Journal of Business Research, pp. 109-116.

Busch, P. and R.F. Bush. 1978. "Women Contrasted to Men in the Industrial Sales Force: Job Satisfaction, Values, Role Clarity, and Propensity to Leave," vol 15, Journal of Marketing Research, (August), pp. 438-448.

Chichilyimov, Vladimir. 1999. Energiya: Sotsial'nogo bytiya naseleniya srednego goroda Rossii na poroge 21 veka (Taganrog: Izdatel'stvo TRTY). 


\section{William Davidson Institute Working Paper 466}

Chusmir, L.H. 1985. "Motivation of Managers: Is Gender a Factor?” vol 9, Psychology of Women Quarterly, pp. 153-159.

Claessens, Stijn and Simeon Djankov. 1999. "Enterprise Performance and Management Turnover in the Czech Republic,” vol 43, no 4-6 European Economic Review (April), pp. 1115-1124.

Clarke, Simon. 1999. The Formation of a Labour Market in Russia (Northampton MA: Edward Elgar Publishers).

Cohen, A. and G. Lowenberg. 1999. "A Re-examination of the Side-Bet Theory as Applied to Organizational Commitment: A Meta-Analysis,” vol 43 Human Relations pp. 1015-1050.

Cox. 1985.

Cox, T.H., S.A. Lobel and P.L. McLeod. 1991. "Effects of Ethnic Group Cultural Differences in Cooperative and Competitive Behavior on a Group Task," vol 34, Academy of Management Review, pp. 827-847.

Dickenson, R. Peter, David Campbell and Vladimir Azarov. 2000. "Will Western Managerial Methods Work in Transitional Societies?” vol 47, no 3, Problems of Post-Communism (May/June), pp. 48-56.

Djankov, Simeon and Peter Murrell. 2000. "Enterprise Restructuring in Transition: A Quantitative Survey," unpublished manuscript, University of Maryland (April).

Dowling, P.J. and R.S. Schuler. 1990. International Dimensions of Human Resource Management (Boston: PWS Kent Publishers).

Dubinsky, Alan, Marvin Jolson, Ronald Michaels, Masaaki Kotabe and Chae Un Lim. 1993. "Perceptions of Motivational Components: Salesmen and Saleswomen Revisited," vol 13, no 4 Journal of Personal Selling and Sales Management (Fall), pp. 25-37.

Earle, John and Almos Telegdy. 1998. "The Results of Mass Privatization in Romania: A First Empirical Study," Economics of Transition, vol 6 no 2 (November), pp. 313-332.

Ericson, Richard E. 1996. "Restructuring Industry During Transition: A Two Period Model," Columbia University, Department of Economics Working Paper, no 9697-03 (September).

Ernst, Maurice, Michael Alexeev and Paul Marer. 1996. Transforming the Core: Restructuring Industrial Enterprises in Russia and Central Europe (Boulder: Westview Press).

Filatotchev, Igor, Mike Wright and Michael Bleaney. 1999. "Privatization, Insider Control and Managerial Entrenchment in Russia," Economics of Transition, vol 7, no 2 (October), pp. 481-504.

Fisher, Cynthia D and Anne Xue Ya Yuan. 1998. "What Motivates Employees? A Comparison of US and Chinese Responses," vol 9, no 3 International Journal of Human Resource Management , pp. 516528.

Friebel, Guido and Sergei Guriev. 2000. "Why Russian Workers Do Not Move: Attachment of Workers through In-Kind Payments," CEPR Discussion Papers (January). 


\section{William Davidson Institute Working Paper 466}

Futrell, C.M. 1980. "Salesmen and Saleswomen Job Satisfaction," vol 9, Industrial Marketing Management (February), pp. 27-30.

Gaddy, Clifford and Barry Ickes. 1998. "Russia's Virtual Economy," Foreign Affairs (September-October), pp. 53-67.

Gimpelson, Vladimir and Douglas Lippoldt. 2001. The Russian Labour Market: Between Transition and Turmoil (New York: Rowman \& Littlefield Publishers).

Glinksaya, Elena and Thomas Mroz. 1996. “The Gender Wage Gap in Russia from 1992 to 1995,” unpublished paper, Carolina Population Center, University of North Carolina.

Granick, David. 1987. Job Rights in the Soviet Union (New York: Cambridge University Press).

Gregory, Paul and Janet Kohlhase. 1988. "The Earnings of Soviet Workers: Evidence from the Soviet Interview Project,” vol 70 Review of Economics and Statistics, pp. 23-35.

Grushin, Boris. 1980. Massovaya informatsiya v sovetskom prom'shlyennom gorod (Moscow: Izdatel'stvo politicheskoi literaturi).

Hauslohner. 1987.

Hofstede, G.H. 1980. "Motivation, Leadership and Organization: Do American Theories Apply Abroad?" Organizational Dynamics (Summer), pp. 42-63.

Hrebiniak, L.G. 1974. "Effects of Job Level and Participation on Employee Attitudes and Perceptions of Influence," vol 17, Academy of Management Journal , pp. 649-662.

Huddleston, Patricia and Linda K. Good. 1999. "Job Motivators in Russian and Polish Retail Firms," International Journal of Retail \& Distribution Management vol 27, no 9, pp. 383-392.

Ivancevich, J.M., R.S. DeFrank, and P.R. Gregory. 1992. "The Soviet Enterprise Director: An Important Resource Before and After the Coup,” vol 6, no 1, Academy of Management Executive, pp. 42-55.

Izyumov, Alexei, Leonid Kosals and Rosalina Ryvkina. 2000. "Defense Industry Transformation in Russia: Evidence from a Longitudinal Survey," Post-Communist Economies, vol 12, no 2 (June), pp. 215228.

Jamal, Muhammad. 1999. "Job Stress and Employee Well-Being: A Cross-Cultural Empirical Study," Stress Medicine, vol 15, pp. 153-158.

Jones, Derek C. 1998. "The Economic Effects of Privatization: Evidence from a Russian Panel," Comparative Economic Studies, vol 40 no 2 (Summer), pp. 75-102.

Kirkcaldy, Bruce and James A. Athanasou. 1999. "Perceptions of Working Climate: A Study of German Employees," Career Development International vol 4, no 1, pp. 53-56. 


\section{William Davidson Institute Working Paper 466}

Kolev, Alexandre.1998. "Labour Supply in the Informal Economy in Russia during Transition," CEPR Discussion Papers (November).

Kovach, K.A. 1987. "What Motivates Employees? Workers and Supervisors Give Different Answers," vol 30 , no 5 Business Horizons, pp. 58-65.

Krueger, Gary. 2002. Between Two Fires: Russian Industry in Transition. in process.

Krueger, Gary and Susan J. Linz. 2001. "Virtual Reality: Barter and Restructuring in Russian Industry," unpublished manuscript, Mic higan State University, presented at AAASS meetings, Washington D.C. (November).

Lacy, W.B, J.L. Bokemeier, and J.M. Shepard. 1983. "Job Attribute Preference and Work Commitment of Men and Women in the United States," vol 36, Personnel Psychology , pp. 315-329.

Ledeneva. 1999.

Linz, Susan J. 1995. "Russian Labor Market in Transition," Economic Development and Cultural Change, vol. 43, no 4 (July), pp. 693-716.

Linz, Susan J. 1995. "Do Job Rights Govern Employment Patterns in Transition Economies?” American Economic Review, Papers and Proceedings, vol 85, no 2 (May), pp. 425-431.

Linz, Susan J. 1996. "Gender Differences in the Russian Labor Market," Journal of Economic Issues, vol 30, no 1 (March), pp. 161-185.

Linz, Susan J. 1997. "Russian Firms in Transition: Champions, Challengers, and Chaff," Comparative Economic Studies vol 39, no 2 (Summer 1997), pp. 1-36.

Linz, Susan J. 1998. “Job Rights in Russian Firms: Endangered or Extinct Institution?" Comparative Economic Studies vol 40 no 4 (Winter), pp. 1-32.

Linz, Susan J. 2001. "Restructuring with What Success? A Case Study of Russian Firms," Comparative Economic Studies vol 43 no 1 (Spring), pp. 75-99.

Linz, Susan J. and Gary Krueger. 1996. "Russia's Managers in Transition: Pilferers or Paladins? ” Post-Soviet Geography and Economics, vol 37, no 7 (September 1996), pp. 397-426

Linz, Susan J. and Gary Krueger. 1998. "Enterprise Restructuring in Russia's Transition Economy: Formal and Informal Mechanisms," Comparative Economic Studies, vol 40, no 2 (Summer), pp. 5-52.

Luthans, Fred, Dianne H.B. Welsh, and S.A. Rosenkrantz. 1993. "What Do Russian Managers Really Do? An Observational Study with Comparisons to U.S. Managers," vol 24, no 4 Journal of International Business Studies, pp. 741-61.

Manning, Nick, Ovsey Shkaratan and Nataliya Tikhonova. 2000. Work and Welfare in the New Russia (Burlington VT: Ashgate Publishing). 
William Davidson Institute Working Paper 466

Mathieu, J.E. and D.M. Zajac. 1990. "A Review and Meta-Analysis of the Antecedents, Correlates, and Consequences of Organizational Commitment," vol 198, Psychological Bulletin, pp. 171-194.

May, R.C. and C.J. Bormann. 1993. "Managerial Practices in the former Soviet Union," vol 1, no 2 Multinational Business Review, pp. 66-75.

McCarthy, D.J. and Sheila Puffer. 1992. "Perestroika at the Plant Level," vol 27, no 1, Columbia Journal of World Business, pp. 86-99.

Meyer and Allen. 1984.

Millar, James R. (ed) 1987. Politics, Work and Daily Life in the USSR (New York: Cambridge University Press).

Miller, Jane and Kenneth Wheeler. 1992. "Unraveling the Mysteries of Gender Differences in Intenions to Leave the Organization," vol 13, Journal of Organizational Behavior , pp. 465-478.

Mowday, R.T. R.M. Steers, and L.S. Porter. 1979. The Measurement of Organizational Commitment, Journal of Vocational Behavior, pp. 224-247.

Mowday, R.T., L.W. Porter and R.M. Steers. 1982. Employee-Organizational Linkages (New York: Academic Press).

Newell, A. and Barry Reilly. 1996. "The Gender Wage Gap in Russia: Some Empirical Evidence,” vol 3, Labour Economics , pp. 337-356.

Ofer, Gur and Aaron Vinokur. 1992. The Soviet Household Under the Old Regime (New York: Cambridge University Press).

Petri, H.L. 1981. Motivation: Theory and Research (Belmont CA: Wadsworth Publishing).

Price, J.L. and C.W. Mueller. 1986. Handbook of Organizational Measurement (Marshfield MA: Pitman Publishers).

Polonsky, Gennady and Zavan Aivazian. 2000. "Restructuring Russian Industry: Can it Really be Done?" Post-Communist Economies, vol 12, no 2 (June), pp. 229-240.

Puffer, Sheila M. 1997. "Soviet and American Managers' Reward Allocations: A Dependency Approach," vol 6, no 5 International Business Review, pp. 453-476.

Reilly, Barry. 1999. “The Gender Pay Gap in Russia During the Transition: 1992-1996,” vol 7 no 1, Economics of Transition, pp. 245-264.

Rimashevskaya, Nataliya. 1997. "The Social Consequences of Economic Transformation in Russia," SOTSIS, no 6, pp. 59-60.

Shama, A. 1993. "Management Under Fire: The Transformation of Managers in the Soviet Union and Eastern Europe," vol 7, no 1 Academy of Management Executive , pp. 22-32. 


\section{William Davidson Institute Working Paper 466}

Shaw, J.B., C.D. Fisher and W.A. Randolph. 1991. "From Materialism to Accountibility: The Changing Cultures of Ma Bell and Mother Russia," Academy of Management Executive, vol 5, no 1, pp. 7-20.

Sherr et al 1991.

Silverthorne, C.P. 1992. "Work Motivation in the United States, Russia, and the Republic of China (Taiwan): A Comparison," vol 22, no 20, Journal of Applied Social Psychology, pp. 1631-1639.

Smith et al. 1969.

Stake, Jayne. 1983. "Factors in Reward Distribution: Allocator Motive, Gender, and Protestant Ethic Endorsement," vol 44 no 2, Journal of Personality and Social Psychology, ppl 410-418.

Standing, Guy (ed). 1991. In Search of Flexibility: The New Soviet Labor Market (Geneva: ILO).

Standing, Guy. 1996. Russian Unemployment and Enterprise Restructuring: Reviving Dead Souls (New York: St. Martin's Press).

Treisman, Daniel. 2000. "Inter-enterprise Arrears and Barter in the Russian Economy," Post-Soviet Affairs, vol 16, no 3 (July-September), pp. 225-256.

United Nations Development Program. 1998. Poverty in Transition? (New York: United Nations).

Upchurch ,Randall S., Robert Davis, and Oleg Sverdlin. 2000. "Motivation of the Russian Worker: An Evolutionary Process," vol 21 Tourism Management , pp. 509-514

Vlachoutsicos, C. and P. Lawrence. 1990. "What We Don't Know about Soviet Management," Harvard Business Review, vol 68, pp. 50-64.

Vroom, V.H. 1964. Work and Motivation (New York: John Wiley \& Sons).

Vroom, V.H. 1990. Managing People, Not Personnel: Motivation and Performance Appraisal (Cambridge: Harvard University Press).

Welsh, Dianne, Fred Luthans, and Steven Sommer. 1993a. "Managing Russian Factory Workers: The Impact of U.S.-based Behavioral and Participative Techniques, Academy of Management Journal, vol 36, pp. 58-79.

Welsh, Dianne, Fred Luthans, and Steven Sommer. 1993b. "Changing Performance among Russian Retail Workers: Effectively Transferring American Management Techniques," vol 6, no 2, Journal of Organizational Change, pp. 34-50.

Zaslavskaya, Tatyana I. 1995. "The Socio-economic Structure of Russian Society," no 6, Ekonomicheskiye i sotsial'niye peremeny, pp. 7-13. 


\section{DAVIDSON INSTITUTE WORKING PAPER SERIES - Most Recent Papers}

The entire Working Paper Series may be downloaded free of charge at: www.wdi.bus.umich.edu

CURRENT AS 5/9/02

\begin{tabular}{|c|c|c|}
\hline Publication & Authors & Date \\
\hline $\begin{array}{l}\text { No. 466: Motivating Russian Workers: Analysis of Age and Ge nder } \\
\text { Differences }\end{array}$ & Susan J. Linz & Feb. 2002 \\
\hline No. 465: Virtual Reality: Barter and Restructuring in Russian Industry & Gary Krueger and Susan J. Linz & Apr. 2001 \\
\hline $\begin{array}{l}\text { No. 464: Lending of Last Resort, Moral Hazard and Twin Crises: } \\
\text { Lessons from the Bulgarian Financial Crisis 1996/1997 }\end{array}$ & $\begin{array}{l}\text { Michael Berlemann, Kalin } \\
\text { Hristov and Nikolay Nenovsky }\end{array}$ & May 2002 \\
\hline $\begin{array}{l}\text { No. 463: Deindustrialisation. Lessons from the Structural Outcomes of } \\
\text { Post-Communist Transition }\end{array}$ & $\begin{array}{l}\text { Tomasz Mickiewicz and Anna } \\
\text { Zalewska }\end{array}$ & Jan. 2002 \\
\hline $\begin{array}{l}\text { No. 462: Joint Liability Lending and the Rise and Fall of China's } \\
\text { Township and Village Enterprises }\end{array}$ & Albert Park and Minggao Shen & July 2001 \\
\hline $\begin{array}{l}\text { No. 461: A Refinancing Model of Decentralization with Empirical } \\
\text { Evidence from China }\end{array}$ & Albert Park and Minggao Shen & Apr. 2002 \\
\hline $\begin{array}{l}\text { No. 460: The Effects of Market Liberalization on the Relative Earnings } \\
\text { of Chinese Women }\end{array}$ & $\begin{array}{l}\text { Margaret Maurer-Fazio and } \\
\text { James Hughes }\end{array}$ & Mar. 2002 \\
\hline $\begin{array}{l}\text { No. 459: The Role of Education in Determining Labor Market } \\
\text { Outcomes in Urban China's Transitional Labor Markets }\end{array}$ & Margaret Maurer-Fazio & Apr. 2002 \\
\hline $\begin{array}{l}\text { No. 458: Real and Monetary Convergence within the European Union } \\
\text { and Between the European Union and Candidate Countries: } \\
\text { A Rolling Cointegration Approach }\end{array}$ & $\begin{array}{l}\text { Josef C. Brada, Ali M. Kutan and } \\
\text { Su Zhou }\end{array}$ & Apr. 2002 \\
\hline No. 457: Credit Ratings as Coordination Mechanisms & $\begin{array}{l}\text { Arnoud W. A. Boot and Todd T. } \\
\text { Milbourn }\end{array}$ & Mar. 2002 \\
\hline $\begin{array}{l}\text { No. 456: Balkan and Mediterranean Candidates for European Union } \\
\text { Membership: The Convergence of their Monetary Policy with that of the } \\
\text { European Central Bank }\end{array}$ & Josef C. Brada and Ali M. Kutan & Apr. 2002 \\
\hline $\begin{array}{l}\text { No. 455: Russian Financial Transition: The Development of Institutions } \\
\text { and Markets for Growth }\end{array}$ & David M. Kemme & Oct. 2001 \\
\hline $\begin{array}{l}\text { No. 454: Does the Market Pay Off? Earnings Inequality and Returns to } \\
\text { Education in Urban China }\end{array}$ & Xiaogang $\mathrm{Wu}$ and $\mathrm{Yu} \mathrm{Xie}$ & Apr. 2002 \\
\hline $\begin{array}{l}\text { No. 453: Entrepreneurs' Access to Private Equity in China: } \\
\text { The Role of Social Capital }\end{array}$ & Bat Batjargal and Mannie M. Liu & Apr. 2002 \\
\hline $\begin{array}{l}\text { No. 452: The Determinants of Privatised Enterprise Performance in } \\
\text { Russia }\end{array}$ & $\begin{array}{l}\text { Alan A. Bevan, Saul Estrin, Boris } \\
\text { Kuznetsov, Mark E. Schaffer, } \\
\text { Manuela Angelucci, Julian } \\
\text { Fennema and Giovanni } \\
\text { Mangiarotti }\end{array}$ & June 2001 \\
\hline $\begin{array}{l}\text { No. 451: Determinants of Financial Distress: What Drives Bankruptcy } \\
\text { in a Transition Economy? The Czech Republic Case }\end{array}$ & Lubomír Lízal & Jan. 2002 \\
\hline No. 450: Corporate Governance and the Global Social Void & Lee A. Tavis & Oct. 2001 \\
\hline $\begin{array}{l}\text { No. 449: Financial Architecture and Economic Performance: } \\
\text { International Evidence }\end{array}$ & Solomon Tadesse & Aug. 2001 \\
\hline $\begin{array}{l}\text { No. 448: Growth Slowdown Under Central Planning: A Model of Poor } \\
\text { Incentives }\end{array}$ & Zuzana Brixiová and Aleš Bulír & Mar. 2002 \\
\hline $\begin{array}{l}\text { No. 447: Disentangling Treatment Effects of Polish Active Labor } \\
\text { Market Policies: Evidence from Matched Samples }\end{array}$ & $\begin{array}{l}\text { Jochen Kluve, Hartmut Lehmann, } \\
\text { and Christoph M. Schmidt }\end{array}$ & Jan. 2002 \\
\hline $\begin{array}{l}\text { No. 446: The Impact of Socialist Imprinting and Search for Knowledge } \\
\text { on Resource Change: An Empirical Study of Firms in Lithuania }\end{array}$ & $\begin{array}{l}\text { Aldas Kriauciunas and Prashant } \\
\text { Kale }\end{array}$ & Mar. 2002 \\
\hline $\begin{array}{l}\text { No. 445: The Costs, Wealth Effects, and Determinants of International } \\
\text { Capital Raising: Evidence from Public Yankee Bonds }\end{array}$ & $\begin{array}{l}\text { Darius P. Miller and John J. } \\
\text { Puthenpurackal }\end{array}$ & Oct. 2001 \\
\hline No. 444: Financial Institutions, Contagious Risks, and Financial Crises & $\begin{array}{l}\text { Haizhou Huang and Chenggang } \\
\mathrm{Xu}\end{array}$ & Nov. 2001 \\
\hline No. 443: Banks as Catalysts for Industrialization & $\begin{array}{l}\text { Marco Da Rin and Thomas } \\
\text { Hellmann }\end{array}$ & Oct. 2001 \\
\hline
\end{tabular}

